\title{
MANAGEMENT MODELS AND DEVELOPMENT OF SHOW CAVES AS TOURIST DESTINATIONS IN CROATIA
}

\section{MODELI UPRAVLJANJA IN RAZVOJA TURISTIČNIH JAM KOT TURISTIČNIH CILJEV NA HRVAŠKEM}

\author{
Neven BOČIĆ ${ }^{1}$, Aleksandar LUKIĆ ${ }^{1} \&$ Vuk Tvrtko OPAČIĆ ${ }^{1}$
}

\begin{abstract}
UDC 551.44:338.48 (497.5)

65.012 .43 (497.5):551.44

Neven Bočić, Aleksandar Lukić \& Vuk Tvrtko Opačić: Management Models and Development of Show Caves as Tourist Destinations in Croatia

Touristic valorisation of caves has long tradition in Croatia. Research has been conducted in order to: identify show caves in Croatia (13), make an overview of their basic geomorphologic characteristics and study their role as tourist destinations. Based on Nature Protection Law and current experiences, four different management models have been identified. Management models have been recognized as an important factor for touristic valorisation of show caves. These elements as well as linkages of show caves with local economy have been examined in more details in case studies. Paper concludes with overview on current tourist development of show caves in Croatia and proposes some future actions in that respect.

Keywords: show cave, management model, tourist destination, local economy, sustainable development, Croatia.
\end{abstract}

Izvleček

UDK 551.44:338.48 (497.5)

65.012 .43 (497.5):551.44

Neven Bočić, Aleksandar Lukić \& Vuk Tvrtko Opačić: Modeli upravljanja in razvoja turističnih jam kot turističnih ciljev na Hrvaškem

Turistično vrednotenje jam ima na Hrvaškem že dolgo tradicijo. Raziskava je želela sledeče: identificirati turistične jame na Hrvaškem (13), napraviti pregled njihovih geomorfoloških značilnosti in preučiti vlogo jam kot turističnih ciljev. Temelječ na Zakonu o varstvu narave in na izkušnjah so bili ugotovljeni štirje modeli upravljanja. Ti so bili spoznani za pomembne dejavnike pri turistični oceni turističnih jam. Tako te sestavine kot tudi povezava turističnih jam s krajevnim gospodarstvom so bili podrobno preučeni v tem prispevku. Članek sklene pregled tekočega turističnega razvoja jam na Hrvaškem in predlaga na tej osnovi nekaj bodočih ukrepov.

Ključne besede: turistična jama, model upravljanja, turistični cilj, krajevno gospodarstvo, trajnostni razvoj, Hrvaška.

\section{INTRODUCTION}

Speleological features as special natural phenomena in karst make the components of tourist attraction basis (Kušen, 2002). The caves having geomorphologic, geological, biological, archaeological, paleontological, landscape and/or other significances, can be touristically valorised. People visit caves out of aesthetic-emotional, recreational, educative and sometimes medical reasons.
Speleological phenomena can be touristically valorised in several fundamental ways. Classical tourist cave arrangement is the most often. It implies accommodation of a cave and its surroundings to a visitor, who has no experience in walking in the country and by caves (Cigna \& Buri, 2000). Tradition of tourist cave valorisation is long in Croatia (Božić, 1984). Gospodska špilja near

\footnotetext{
${ }^{1}$ Department of Geography, Faculty of Science, University of Zagreb, Marulićev trg 19, 10000 Zagreb, Croatia e-mail: nbocic@geog.pmf.hr ; alukic@geog.pmf.hr ; vtopacic@geog.pmf.hr
}

Received/Prejeto: 15.09.2006 
the source of the river Cetina can be considered the first touristically arranged cave. It was arranged for organised visits as early as 1855 . The longest tradition belongs to the Modra špilja on the island of Biševo (visited since 1884) and the Gornja Baraćeva cave near Rakovica, first arranged in 1892, and reopened in 2003. The research purpose is to state, on the basis of standard criteria, which speleological features in Croatia are included in the cat- egory of tourist caves, how and to what extent are they touristically valorised and what possible role they play in the local economy of the surrounding area considering sustainable development. Božičević (1961), Pepeonik (1982) and Božić (1999) published works about tourism valorisation of caves in Croatia, but without analysing the problematics of management of show caves.

\section{METHODS}

The first task was to define the notion of a tourist cave on the basis of previous domestic and foreign experiences and to single out such phenomena in Croatia (Cigna \& Buri, 2000; Božić, 1999). Dealing with the defined tourist caves we had to collect the data about: their location, total length, length of the touristically arranged path, year of the first opening, number of visits, way of management and protection category. On the basis of the collected data, especially about the management of a show caves, four case studies have been worked out. Besides the basic comparison of geomorphologic and other features, the greatest part of the research was done in the field. By a questionnary survey of the show cave management there were determined initiatives and beginnings of the cave's introduction into the tourist offer, modern way of tourism valorisation (number and structure of visitors, incomes, seasonality, etc.), the cave's role in the tourist offer of the destination, connection with the local area, ways of protection and orientation towards sustainable development.

\section{LEGAL CONTEXT OF CAVE MANAGEMENT IN CROATIA}

Nature protection in Croatia depends largely on laws and regulations, which are passed not only to preserve natural resources from exploitation, but also to protect the endangered species. Croatian laws on nature protection have a long tradition. First laws of that kind were Bird Protection Act (1893), Hunting Act (1893) and Cave Protection Act (1900) (Opačić, 2001, Opačić et al., 2004). The basic legal document for nature protection nowadays is Nature Protection Act from 2003.

From the aspect of property and government, and thereby from that of protection and management in speleological phenomena, this law has introduced several essential innovations. The first one is "speleological phenomena are owned by the Republic of Croatia“ (par 47, NN 70/2005). In that way all speleological phenomena in Croatia come within the competence of the Nature Protection Law. Some speleological phenomena can be additionally protected by the natural monument status or be located within some other protected areas (e. g. Natural Park, National Park...). The other innovation relates to possible ways of management in tourist speleological phenomena. The Law defines two basic management models: 1) through a public institution, and 2) through concession or concession approval. If a speleological phenomenon is located in the protected area managed by a public institution (Natural Park and National Park), the same institution manages it, too. If a speleological phenomenon is located out of a Natural Park or National Park, it is managed by a county public institution for managing the protected areas. Regardless of the phenomenon's location (whether it is situated in or out of a Natural Park or National Park), a concession or its approval is possible. This Law has put aside a long-standing practice that local tourist societies can manage speleological phenomena. Nevertheless, as the Law is relatively new, we still come upon the mentioned practice. 


\section{EXAMPLES OF MANAGEMENT OF SOME SHOW CAVES IN CROATIA}

On the basis of the defined criteria (arranged and secured path, lighting, guides, arranged approach and the management body controlling the cave's work) thirteen show caves in Croatia have been determined. It was found that arrangement, way of valorisation, inclusion into tourist destinations, protection and linkages with the local economy primarily depended on the management form

\begin{tabular}{|c|c|c|c|c|c|c|}
\hline $\begin{array}{l}\text { Name of the } \\
\text { cave }\end{array}$ & Location & $\begin{array}{l}\text { Length of } \\
\text { the cave }\end{array}$ & $\begin{array}{l}\text { Length of } \\
\text { the touristic } \\
\text { path }\end{array}$ & $\begin{array}{l}\text { Year of } \\
\text { the first } \\
\text { opening }\end{array}$ & $\begin{array}{l}\text { Models of the cave } \\
\text { management }\end{array}$ & Category of protection \\
\hline Vrlovka & $\begin{array}{l}\text { Kamanje, County of } \\
\text { Karlovac }\end{array}$ & $380 m$ & $330 m$ & 1928 & $\begin{array}{l}\text { Local authorities through local } \\
\text { public institution }\end{array}$ & $\begin{array}{l}\text { Geomorphologic } \\
\text { monument of nature since } \\
1962 .\end{array}$ \\
\hline Veternica & Medvednica, City of Zagreb & $7118 m$ & $380 \mathrm{~m}$ & 1951 & $\begin{array}{l}\text { Management board of } \\
\text { protected area (Park of nature } \\
\text { Medvednica) }\end{array}$ & $\begin{array}{l}\text { Geomorphologic } \\
\text { monument of nature since } \\
\text { 1979., in area of Nature } \\
\text { Park Medvednica since } \\
1981 .\end{array}$ \\
\hline $\begin{array}{l}\text { Donja } \\
\text { Cerovačka }\end{array}$ & Gračac, County of Zadar & $2682 m$ & $700 \mathrm{~m}$ & 1976 & $\begin{array}{l}\text { Management board of } \\
\text { protected area (Park of nature } \\
\text { Velebit) }\end{array}$ & $\begin{array}{l}\text { Geomorphologic } \\
\text { monument of nature since } \\
\text { 1961., in area of Nature } \\
\text { Park Velebit since } 1981 .\end{array}$ \\
\hline Baredine & Nova Vas, County of Istria & $120 m$ & $120 \mathrm{~m}$ & 1994 & $\begin{array}{l}\text { Private enterpreneur through } \\
\text { concession for cave on private } \\
\text { (own) land }\end{array}$ & $\begin{array}{l}\text { Geomorphologic } \\
\text { monument of nature since } \\
1986 .\end{array}$ \\
\hline $\begin{array}{l}\text { Gornja } \\
\text { Baraćeva }\end{array}$ & $\begin{array}{l}\text { Rakovica, County } \\
\text { of Karlovac }\end{array}$ & $520 \mathrm{~m}$ & $200 m$ & 1892 & $\begin{array}{l}\text { Local authorities through local } \\
\text { public institution }\end{array}$ & - \\
\hline Špilja Vrelo & $\begin{array}{l}\text { Fužine, County } \\
\text { of Primorje-Gorski kotar }\end{array}$ & $310 \mathrm{~m}$ & $180 \mathrm{~m}$ & 1965 & $\begin{array}{l}\text { Local authorities through local } \\
\text { public institution }\end{array}$ & - \\
\hline Lokvarka & $\begin{array}{l}\text { Lokve, County } \\
\text { of Primorje-Gorski kotar }\end{array}$ & $1100 \mathrm{~m}$ & $435 m$ & 1935 & $\begin{array}{l}\text { Private enterpreneur through } \\
\text { concession for cave on public } \\
\text { land }\end{array}$ & $\begin{array}{l}\text { Geomorphologic } \\
\text { monument of nature since } \\
1961 .\end{array}$ \\
\hline Vranjača & $\begin{array}{l}\text { Dugopolje, County } \\
\text { of Split-Dalmatia }\end{array}$ & $180 m$ & $160 m$ & 1929 & $\begin{array}{l}\text { Private enterpreneur through } \\
\text { concession for cave on private } \\
\text { (own) land }\end{array}$ & $\begin{array}{l}\text { Geomorphologic } \\
\text { monument of nature since } \\
1963 .\end{array}$ \\
\hline Manita peć & $\begin{array}{l}\text { Starigrad-Paklenica, County } \\
\text { of Zadar }\end{array}$ & $175 m$ & $200 m$ & 1935 & $\begin{array}{l}\text { Management board of } \\
\text { protected area (National park } \\
\text { Paklenica) }\end{array}$ & $\begin{array}{l}\text { In area of National Park } \\
\text { Paklenica since } 1949 .\end{array}$ \\
\hline Samograd & Perušić, County of Lika-Senj & $220 m$ & $220 \mathrm{~m}$ & 1903 & $\begin{array}{l}\text { Local authorities through local } \\
\text { public institution }\end{array}$ & $\begin{array}{l}\text { Geomorphologic } \\
\text { monument of nature since } \\
1964 .\end{array}$ \\
\hline Grgosova & Samobor, City of Zagreb & $60 m$ & $20 m$ & 1974 & $\begin{array}{l}\text { Private enterpreneur through } \\
\text { concession for cave on private } \\
\text { (own) land }\end{array}$ & $\begin{array}{l}\text { Geomorphologic } \\
\text { monument of nature since } \\
1974 .\end{array}$ \\
\hline Modra špilja & $\begin{array}{l}\text { Biševo, County } \\
\text { of Split-Dalmatia }\end{array}$ & $36 m$ & $36 m$ & 1884 & $\begin{array}{l}\text { Local authorities through local } \\
\text { public institution }\end{array}$ & $\begin{array}{l}\text { Geomorphologic } \\
\text { monument of nature since } \\
1951 .\end{array}$ \\
\hline Biserujka & $\begin{array}{l}\text { Krk, County } \\
\text { of Primorje-Gorski kotar }\end{array}$ & $110 m$ & $65 \mathrm{~m}$ & 1967 & $\begin{array}{l}\text { Local authorities through local } \\
\text { public institution }\end{array}$ & - \\
\hline
\end{tabular}

Tab.1: Main features of show caves in Croatia 


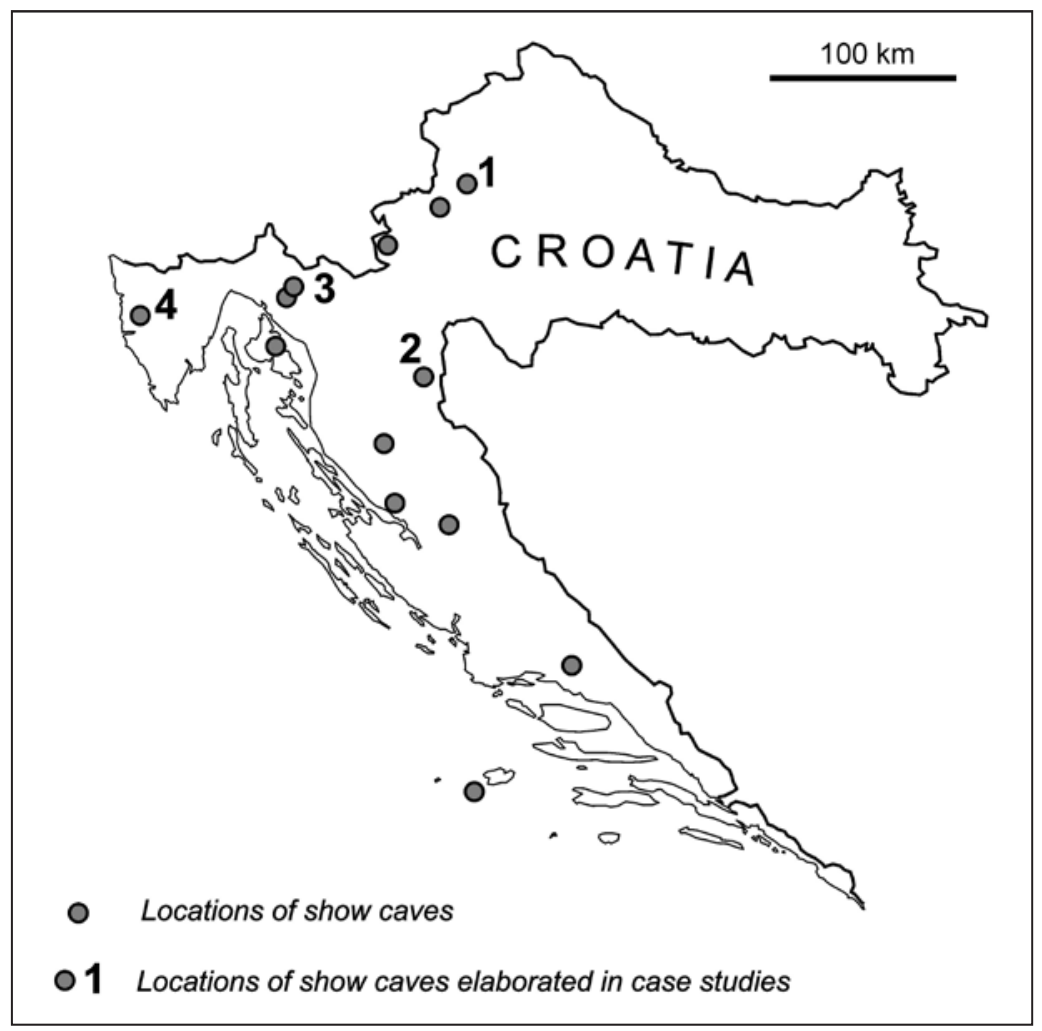

Fig.1: Distribution of show caves in Croatia and location of case-studies into account. Therefore, the cave Veternica should not be considered as a part of the Zagreb city tourist destination, but as a tourist locality in the Nature Park Medvednica, where the sojourn tourism is still in the background. The majority of visitors are organised groups of pupils, families, mountaineers - in one-word hikers, primarily from Zagreb, who visit the cave from the beginning of April to the beginning of November. Maximal number of visits is registered during spring (April, May, the beginning of June) and autumn months (the end of September, October), which corresponds with the school year, as well as with the weather conditions favourable for excursions. Although the number of visits is relatively small $(2,500$ 3,000 in recent years), the Park's management board thinks that in the future cave's management more care should be taken about its protection than about eventual tourist visits enlargement. The share of the Veternica cave in the total independently realised profit of the Nature Park Medvednica decreased from $22 \%$ in 2002 to $12 \%$ in 2005 .
Four distinctive types of cave management have been identyfied: (cave is managed by): a) management board of protected area, b) private enterpreneur through concession for cave on public land, c) private enterpreneur through concession for cave on private (own) land, d) local authorities through local public institution. Because of differences among the analysed parameters, especially dealing with the way of management, there were elaborated case studies for the following show caves: the cave Veternica on Medvednica near Zagreb, Lokvarka near Lokve in Gorski Kotar, Baraćeve caves near Rakovi$\mathrm{ca}$ and the pit Baredina near Poreč.

\section{Example 1. Veternica cave - operated by management board of protected area}

The cave Veternica, situated on the south-western part of Medvednica is 7,100 m long. In 1951, it was opened for tourists in the length of $380 \mathrm{~m}$. Malinar (1984) wrote about beginnings of tourism valorisation of Veternica cave. Since, as a geomorphological monument of nature, it is situated in the protected area, the Public Institution Nature Park Medvednica is responsible for its management. As this is a protected area, the basic purpose of its management is its protection, then tourist, i. e. educative visits, in the course of which the sustainable development postulates are especially taken
Example 2. Baraćeve caves - run by local authorities through local public institution

Baraćeve Caves (Gornja and Donja - Upper and Lower) are situated near the village Nova Kršlja in the municipality of Rakovica. Baraćeve Caves were among the first touristically arranged caves in the continental part of Croatia. Garašić (1989) wrote abot touristic potential of surrounding of Baraćeve Caves. They were opened for tourists in 1892, but did not fill that function for a long period. Owing to the efforts of the Rakovica municipality the Gornja Baraćeva cave was arranged in 2003 and opened in 2004. It is $520 \mathrm{~m}$ long, and the length of its tourist path figures out at about $200 \mathrm{~m}$. The main attraction of the cave is a variety of dripstone forms, archaeological and palaeontological remains, as well as an interesting ambience in front of the cave's entrance. Besides the illuminated path in the cave, the surroundings were arranged too (promenade and excursion centre by the karst source Baraćevac). An instructive path about karst is in preparation. In 2004, the Gornja Baraćeva cave was visited by 4,800 visitors. Although it is a matter of increase, this is still a too small number of visitors for such a natural tourist attraction, which lies against the nearby Plitvice Lakes. Owing to its favourable position, the Baraćeva cave relies on foreign guests in high tour- 
ist season, and on domestic ones (mostly groups) in the off-season period. The cave is managed by the local government (municipality of Rakovica) through the Public Institution for Managing Protected Natural Values throughout the area of the municipality of Rakovica.

Example 3. Lokvarka cave - managed by private enterpreneur through concession for cave on public land

The cave Lokvarka is located in Lokve, a settlement in Gorski Kotar near Delnice. It was discovered in $1911 / 1912$, and in 1935, a part of it was electrified and opened for visits. The cave was arranged on several occasions (1961, 1973-74). The Tourist Community Lokve ran the cave till the first half of the 1990s, when the public institution Croatian Forestry overtook the management for a short time, and by the mid-1990 it was overtaken by a private concessionaire. The concession was approved for three years, and then it had to be prolonged every year. In 2005, the number of sold tickets amounted to some 7,000 , although the number of visits was somewhat larger (free entrances for associations, etc.). In that time, the cave was permanently opened from 1 May to 1 October, and the visits accompanied by guide services were fixed from 10 to 19 oclock. In the remaining months the cave could be visited having made a preliminary announcement. Group visits of the Croatian pupils dominated in the visitor structure. As to the other group visits, we must single out foreign guests (especially the German), who visited the cave in the course of one-day trips to Gorski Kotar organised by the travel agency, which managed the cave. Between 20 June and 1 September (during school holidays), individual guests from the country and abroad dominated. During his management, the concessionaire did only the necessary infrastructure maintaining (staircase handholds, painting, electric power, and similar), because he had no finances for greater interventions, e. g. a complete replacement of three steep staircases. The aggravating circumstance in the cave management was the risk of long-term investments in such a short-term concession (1 year). Since the spring of 2006, the cave has been managed by the Tourist Community Lokve. Considerations about further tourist valorisation and management in the framework of the local government are in progress.
Example 4. Baredine pit - managed by private enterpreneur through concession for cave on private (own) land

The pit Baredine is the youngest, but also, by the number of visitors, touristically the most important speleological feature in Croatia. It is also the first touristically arranged pit in the Croatian part of Istria (Dečak, 1994). The Baredine was discovered in the nineteen seventies on a private estate in the village of Nova Vas. The activities of the pit's protection and tourist valorisation was initiated by the estate's owner, who was also a caver. He did it by his own finances. Till the mid1990-s a confined number of visitors was allowed to visit the pit through speleoadventure. In 1995, the Baredine was opened for tourist visits (arranged electric lighting and staircase). Between 7,000 and 8,000 tourists visited the pit that year. The number of guests in 2004 and 2005 amounted to about 50,000. From 1 April till 31 October the pit is opened for visitors every day and during the remaining five months only for announced groups. 8 people are permanently employed there, and some additional guides only periodically. As to the visitor structure, individual guests dominate (especially in the summer months at the peak of the tourist season), and the share of foreign visitors is also very significant, especially that of the German, Danish, Dutch, Russian, Italian... Individual visits, mostly out of the summer season, supplement school and expert excursions from Croatia and abroad (Italy, Germany, Belgium, Denmark...). Besides by the speleological feature itself, the visitors are also motivated by the speleothems and Proteus anguinus placed in a natural recess filled with water. The basic function of this pit is tourist, which is also visible from the arrangement of the accompanying attractions (catering establishment, "agro-museum" in the open air, souvenirs sale, sale of original food-stuff, fruit and vegetables, picnic place, exhibition space...). Some 20 families take part periodically in the mentioned accompanying tourist offer. The owner plans to widen the tourist offer and to create a complex tourist product, for which there are corresponding space-planning regulations

\section{MODELS OF MANAGEMENT IN SHOW CAVES IN CROATIA}

In view of the analysed examples and actual legal basis we are dealing with four different models of management tourist caves in Croatia (Fig. 2). 


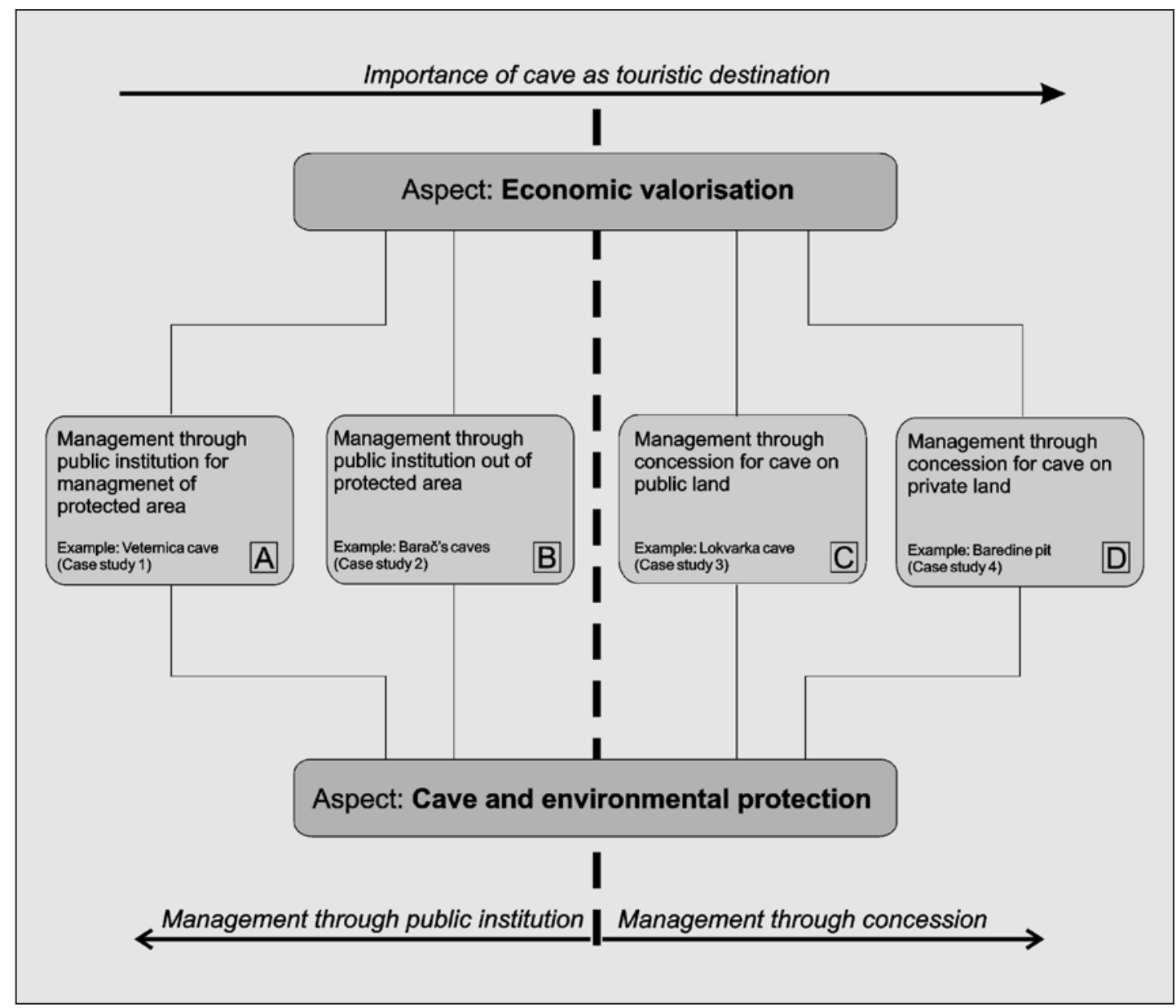

Fig.2: Management models of show caves in Croatia

\section{a) management board of a protected area}

The largest part of the area within the protected regions in Croatia relates to two categories. They are natural parks and national parks, which together account for 90 per cent of all protected Croatian regions. Nature Protection Law says that public institutions manage these two categories. Three show caves belong to this type of management, so they are in the competence of public institutions (Veternica in the Natural Park Medvednica, Cerovac Caves in the Natural Park Velebit, Manita Peć in the National Park Paklenica). ${ }^{1}$ According to the Nature Protection Law, "public institutions...attend to the busi-

\footnotetext{
${ }^{1}$ The Law enables a concession assignment for a speleological phenomenon within National and Natural Parks too. Although there are no such cases in Croatia at the moment, it is interesting to single out the example of the Cerovac Caves. They are located in the Natural Park Velebit, and until recently have been managed by a private concessionaire. Unsatisfied with the management, the public institution of the Natural Park Velebit has overtaken it.
}

ness of protection, maintenance and promotion of the protected area in order to protect and preserve authenticity of nature, to ensure an undisturbed development of natural processes and sustainable use of natural goods, and to supervise the execution of conditions and measures of nature protection in the area of their management" (NN 70/2005). National Park and Natural Park are managed on the basis of a special spatial plan introduced by the Croatian National Parliament, the plan of managing a protected area and regulations about the internal order.

These determinants have really defined the way of evaluation of speleological phenomena in the protected regions. The most important is "preservation of significant and characteristic features of a landscape and maintenance of biological, geological and cultural values, which define its significance and aesthetic experience" (NN 70/2005). Therefore, tourist significance of speleological objects in this management type is subordinate to their protection. Moreover, National and Natural Parks become distinctive as peculiar tourist destinations 
(branding and marketing at the park level), while particular localities in them, e.g. caves and pits, make a part of their attraction offer and have not yet developed into separate tourist destinations. Public institutions make profit out of several different sources: budget, gate receipts in National Parks and speleological phenomena and other own profits. Therefore, dependence on the profits from the "cave" is significantly smaller than under private forms of management.

\section{b) local authorities through a local public institution out of a protected area}

Units of local authorities and self-government (municipalities and towns) on whose territory there is a speleological phenomenon, can manage the phenomenon by giving a concession to a private entrepreneur or, more often, to run it through a local tourist community or through for that purpose established public institution (Baraćeve špilje, Biserujka, Lokvarka ${ }^{2}$, Samograd, Vrelo, Vrlovka).

Consequently, respecting the Croatian Nature Protection Law, a special stress has been laid upon economic exploitation of a speleological phenomenon. Local authority unit realises earnings, therefore it is interested in transformation of a touristically evaluated cave or pit into a peculiar separate destination. The advantage of this management model is in the fact that the management and marketing are being done from the same centre, which can contribute to a more powerful and more durable definition of the cave as an important segment of local tourist offer - and which is not always the case in relation between a private concessionaire and local community.

\section{c) private entrepreneur (through concession) of a cave on public land}

According to the Law a concessionaire can manage a speleological phenomenon. "Concession enables the privilege of economic exploitation of natural resources or that of performing activities of interest to the Republic of Croatia, as well as the privilege for construction and use of facilities necessary for doing those activities in protected areas and speleological phenomena where it is permitted according to this Law (NN 70/2005). Although this way of management was used in Croatia after transfer to market economy (Lokvarka and Cerovac Caves), there is only one speleological phenomenon arranged for tourist visits (submarine Modra Cave on the island of Biševo), where concession has been given to the tourist agencies, which organise visits by vessels. In this case the primary motivation of the concessionaire is financial benefit, while big investments, especially dealing with a contract of short duration, are not profitable. Therefore a concession contract, as well as management supervision, is a necessary measure of protection. According to the available data, a short duration of concessions deepens the gap between financial interests of a concessionaire on the one hand and necessity for a long sustainable evaluation of a cave for tourist purposes on the other. Such situation has resulted in mutual discontents and breaks of cooperation. From the aspect of destination, certain disadvantages of this model can be noticed: the management is in the hands of a concessionaire, and the local authorities take care about development of the destination. Consequently, the relations between the interested parties directly influence tourism valorisation of a speleological phenomenon.

\section{d) private owners of the cave through concession and on his own land}

The law says: "The owner or privilege holder of the land where there is a speleological phenomenon has priority in getting concession or compensation for limitations imposed because of using the speleological phenomenon proportionally to the reduced profit." We consider this Law paragraph the key one in this management model analysis, because it enables continuity in managing, which is the prerequisite of a long sustainable use of the speleological phenomenon. This management form, just as the former one, appeared in Croatia after the transfer to the market economy. Three caves in Croatia (Baredine, Grgosova Cave and Vranjača) are managed on the basis of this model. The land owner, also the concessionaire, is interested in transformation of the speleological phenomenon into an independent tourist destination, the notion of which includes a more complex offer (from accommodation and catering services to accompanying elements such as souvenirs, collections, galleries...). It brings diversification of the concessionaire's product, but also the spill-over of economic effects to the local community. The branding process of the total destination product has also been singled out, but under the name of speleological phenomenon. If this is realised, a show cave or pit becomes an important tourist offer of the region.

\footnotetext{
${ }^{2}$ According to this model, today you can count and Lokvarka cave, although, not so long it was managed through concession on public land (model c). As of such kind it was treated in this work.
} 


\section{CONCLUSIONS}

On the basis of the collected data about show caves in Croatia, as well as on the more analysed case studies, it is possible to draw the following conclusions:

- Although there are 13 speleological features arranged for tourist visits in Croatia, we consider that, regarding attractiveness, traffic accessibility and possibility of an average tourist's visit, there are some more potential caves for tourist valorisation (for example Gvozdenica cave).

- Four distinctive management models have been identifyed: a) management board of protected area, b) private enterpreneur through concession for cave on public land, c) private enterpreneur through concession for cave on private (own) land, d) local authorities through local public institution. They have been recognized as an important factor for tourism valorisation of show caves.

- It has been recognised that the model of management by concession on public land under the existing circumstances has turned out as inadequate, so it is disappearing.

- Although the majority of the show caves in Croatia are protected by a category of a geomorphological monument of nature, their tourism valorisation primarily depends on the way of management. Namely, if a public institution runs a cave (e. g., Nature Park or National
Park), the protection component is more prominent, which is understandable regarding the basic function of the institution, as well as the fact that the profit from the cave does not make the basic element of the public institution profit structure. On the other hand, if a private concessionaire manages a show cave, the business orientation towards tourism is more marked. Consequently, in these cases the connection with local economy is more prominent, just as the significance of the phenomenon within the tourist destinations.

- Having compared our situation with the experiences abroad (Forti \& Cigna, 1989; Ramšak, 2004; Cabezas, 2004; Bartholeyns, 2004), but also on the basis of the specific data about the number of visits, inclusion into the tourist product of destinations and way of valorisation (almost exclusively only a visit), we consider that the majority of the show caves in Croatia are still insufficiently explored.

Actual legal basis, which is the foundation of the cave management in Croatia, is relatively new. Therefore, the presented management models could not completely become a reality. Their continuous observation and evaluation intrudes as an essential factor of the sustainable development of the Croatian karst area.

\section{ACKNOWLEDGEMENTS}

We thank those who helped us unselfishly in our research: Silvio Legović (Jama Baredine), Silvija Barbarić (Tourist Community Lokve), Snježana Malić - Limari (Nature
Park Medvednica), Franjo Franjković, Tihana Rakić (Rakovica Municipality) and Mr. Gašparac from Lokve. 


\section{REFERENCES}

Bartholeyns, J.-P., 2004: Sustainable Development of Show Caves and Protection of a Common Heritage. IV I.S.C.A. International Congress, Postojna, Slovenia 2002, 195-200, Postojna

Božić, V., 1984: Počeci speleološkog turizma u Hrvatskoj. Zbornik predavanja 9. jugoslavenskog speleološkog kongresa, Karlovac 1984, Speleološko društvo Hrvatske, 829-836, Zagreb

Božić, V., 1999: Speleološki turizam u Hrvatskoj-vodič po uređenim i pristupačnim špiljama i jamama. Naklada „Ekološkog glasnika“, p. 168, Zagreb

Božičević, S. 1961: Zaštita pećina u Hrvatskoj i njihovo uređenje u turističke svrhe. Zbornik predavanja 2. jugoslavenskog speleološkog kongresa, Split 1958. Speleološko društvo Hrvatske. 147-154, Zagreb

Cabezas, J., 2004: New Trends in Cave Management. IV I.S.C.A. International Congress, Postojna, Slovenia 2002, 123-128, Postojna

Cigna, A.A. \& Burri, E., 2000: Development, management and economy of show caves. Int. J. Speleol., vol. 29 B, 1-27, Bologna

Dečak, V., 1994: Jama Baredine kod Poreča - prva turistički uređena špilja u Istri. Speleolog, 42-43, 22-24, Zagreb

Forti, P \& Cigna, A.A., 1989: Cave tourism in Italy: an overview. Cave Tourism, Proc. Int. Symp. $170^{\text {th }}$ Anniv. Postojnska jama, Postojna 1988., ZRC SAZU \& Postojnska jama, Ljubljana
Garašić, M., 1989: Surrounding of Barač’s caves - the former show cave - with regard to touristic potential and valorisation. Cave Tourism, Proc. Int. Symp. $170^{\text {th }}$ Anniv. Postojnska jama, Postojna 1988., ZRC SAZU \& Postojnska jama, Ljubljana

Kušen, E., 2002: Turistička atrakcijska osnova. Znanstvena edicija Instituta za turizam, p. 262 , Institut za turizam, Zagreb

Malinar, H., 1984: Zaštita i uređenje špilje Veternice. Zbornik predavanja 9. jugoslavenskog speleološkog kongresa Karlovac 1984., 863-866, Zagreb

Opačić, V.T., 2001: Zaštita prirode - hrvatska šansa za opstanak i razvoj. Hrvatska revija, 1/1, 119-127, Zagreb

Opačić, V.T., Lukić, A. \& Furst-Bjeliš, B., 2004: Sustainable development of recreation and tourism in protected areas of Croatia: issues and indicators. Proccedings of International scientific project: Improving to knowledge base for sustainable managemeof recreational resourses in transitional countries. Koprivštica, Bulgaria 2004, in press

Pepeonik, Z., 1982: The Role of the Caves in the Tourist Offer of Croatia. Le Grotte d'Italiana, (4) X, 109114, Castellana Grotte

Ramšak, S., 2004: Show caves in Slovenia. IV I.S.C.A. International Congress, Postojna, Slovenia 2002, 4954, Postojna 
